\title{
BIG BROTHER IS WATCHING YOU: UMA ANÁLISE DA REGULAÇÃO BRASILEIRA SOBRE DRONES NO TOCANTE À VIOLAÇÃO DA PRIVACIDADE*
}

\author{
Leonardo da Costa Priebe** \\ Alexandre Torres Petry ${ }^{* * *}$
}

\section{RESUMO}

A revolução tecnológica trouxe à ciência do Direito uma série de preocupações. Com o advento das denominadas tecnologias disruptivas, relevantes institutos jurídicos estão sendo progressivamente vulnerabilizados. Este artigo versa sobre a ascensão dos drones e seu potencial de violação ao direito de privacidade, consagrado pela Constituição Federal de 1988 como direito fundamental. Neste cenário, objetiva-se analisar a regulação existente no ordenamento jurídico brasileiro acerca da temática - dissertando, por conseguinte, sobre seus aspectos principais. De tal exame, pois, clarificam-se carências regulatórias essenciais ao resguardo do direito à privacidade, notadamente no que diz respeito ao registro e controle dos drones, ao passo que outros pontos da legislação, a exemplo dos aspectos relacionados à segurança dos civis expostos às operações de voo, mostram-se suficientemente desenvolvidos.

Palavras-chave: Drones. Privacidade. Direito. Tecnologia.

* Artigo apresentado ao Curso de Bacharelado em Direito do Centro Universitário Metodista - IPA, como requisito parcial para obtenção do Grau de Bacharel em Direito.

** Graduando do Curso de Bacharelado em Direito do Centro Universitário Metodista - IPA.

*** Doutor em Educação pela Universidade Federal do Rio Grande do Sul, Mestre em Direito pela Pontifícia Universidade Católica do Rio Grande do Sul, Especialista em Direito do Consumidor e Direitos Fundamentais pela Universidade Federal do Rio Grande do Sul, Especialista em Direito \& Economia pela Universidade Federal do Rio Grande do Sul e professor da Faculdade de Direito do Centro Universitário Metodista - IPA. 


\section{BIG BROTHER IS WATCHING YOU: AN ANALYSIS OF BRAZILIAN REGULATION ON DRONES REGARDING VIOLATION OF PRIVACY}

\section{ABSTRACT}

The technological revolution has brought to the science of Law a number of concerns. With the advent of so-called disruptive technologies, relevant legal institutes are becoming increasingly vulnerable. This article deals with the rise of drones and their potential for violation of the right to privacy, enshrined in the Federal Constitution of 1988 as a fundamental right. In this scenery, the objective is to analyze the existing regulation in the Brazilian legal system on the subject - discussing, therefore, its main aspects. In this way, it is possible to observe regulatory deficiencies essential to safeguarding the right to privacy, especially regarding the registration and control of drones, while other aspects of legislation, such as aspects related to the safety of civilians exposed to flight operations, are sufficiently developed.

Key words: Drones. Privacy. Law. Technology.

\section{INTRODUÇÃO}

No despertar do terceiro milênio, o Direito, tal qual o conhecemos, está em plena reconfiguração. Se, por um lado, novos institutos jurídicos estão sendo forjados, a exemplo do direito digital, outros, clássicos, como a privacidade, demandam atenção especial a partir do surgimento de novas situações e condições com grande potencial de consolidação na sociedade nos próximos anos. Nesta perspectiva, destaca o historiador Yuval Noah Harari", em sua obra intitulada "Homo Deus, uma breve história do amanhã":

Na escala cósmica da história, o gênero humano pode erguer os olhos e começar a perscrutar novos horizontes. Se realmente a fome, a peste e a guerra estão sob controle, o que irá substituí-las como prioridade na agenda humana? Como bombeiros

HARARI, Yuval Noah. Homo Deus: uma breve história do amanhã. Tradução: Paulo Geiger. 1⿳a ed. São Paulo: Companhia das Letras, 2016. p. 12. 
em um mundo sem incêndios, o gênero humano no início do século XXI deve fazer a si mesmo uma pergunta sem precedente: o que vamos fazer conosco? Num mundo saudável, próspero e harmonioso, o que vai exigir nossa atenção e nossa engenhosidade? Essa pergunta torna-se duplamente urgente em razão dos novos e imensos poderes que a biotecnologia e a tecnologia da informação estão nos oferecendo. 0 que vamos fazer com todo esse poder?

O questionamento levantado por Harari, embora deva permanecer sem resposta ainda por algumas décadas, fundamenta uma preocupação geral com o desenvolvimento aparentemente irrefreável das tecnologias, fenômeno que adquiriu a denominação, por parte de alguns teóricos, de quarta revolução industrial. Para Schwab ${ }^{2}$, ainda precisamos compreender de forma mais abrangente a velocidade e amplitude dessa nova revolução, que alterará profundamente a maneira como vivemos, trabalhamos e nos relacionamos.

Tal inquietude, sabe-se, intensifica-se a partir do surgimento de problemas concretos nas mais diversas esferas da vida civil. É o caso, por certo, do advento dos drones ${ }^{3}$, aeronaves não tripuladas em constante popularização na sociedade moderna. Sua tecnologia, utilizada de maneira irresponsável, pode configurar verdadeiro tormento aos direitos individuais - especialmente ao direito fundamental à privacidade, objeto do presente estudo.

Originalmente projetados para utilização exclusiva em operações militares, os drones se popularizaram recentemente no meio

SCHWAB, Klaus. A quarta revolução industrial. Tradução: Daniel Moreira Miranda. 1aㅡ ed. São Paulo: Edipro, 2016. p. 9.

3 O termo drone, embora cunhado e popularizado nos EUA, já integra o vocabulário brasileiro com propriedade, inclusive constando nos maiores dicionários da língua portuguesa. Por tal razão é que suas próximas aparições, ao longo do presente artigo, não sofrerão alterações de formatação. 
civil. São utilizados, atualmente, para os mais diversos fins - do monitoramento ambiental ao lazer -, podendo ser equipados com câmeras capazes de capturar imagens e vídeos em alta resolução ${ }^{4}$.

Por efeito de sua usual imperceptibilidade, estas aeronaves apresentam uma grande potencialidade lesiva em relação à privacidade, de modo que, dentre vários episódios concretos envolvendo sua utilização, alguns vêm ganhando destaque na mídia brasileira, como o do ator Cauã Reymond, fotografado nu, por um drone, no interior de seu apartamento. Tal foi o sentido de invasão experimentado pelo ator, que este decidiu processar o fotógrafo por conta do dano suportado ${ }^{5}$.

Em resposta a esta hodierna e crescente problemática estabelecida com a ascensão dos drones, regulamentações vêm sendo desenvolvidas no mundo todo - e inclusive, recentemente, no Brasil - a fim de, especialmente, assegurar as operações de voo destas aeronaves, sejam elas profissionais ou recreativas, sem que causem riscos a terceiros. Neste sentido, importante é o registro de Marina Castells I Marquès ${ }^{6}$ :

En el caso de drones civiles para usos recreativos, deportivos o cualquier otro uso, [...] interesan los aspectos relacionados con la responsabilidad civil. Los daños que pudiera ocasionar el dron a terceros

4 G1. Com preço menor, 3 milhões de drones devem ser vendidos em 2017, diz consultoria. Disponível em: http://g1.globo.com/tecnologia/noticia/ com-preco-menor-3-milhoes-de-drones-devem-ser-vendidos-em-2017-diz-consultoria.ghtml. Acesso em: 19 abr. 2018.

5 COPLE, Julia. Cauã Reymond decide processar fotógrafo que fez imagens do ator nu dentro de casa. Jornal Extra. Disponível em: https://extra.globo. com/casos-de-policia/caua-reymond-decide-processar-fotografo-que-fez-imagens-do-ator-nu-dentro-de-casa-22296510.html. Acesso em: 13 jun. 2018.

6 No caso de drones civis para recreação, esportes ou qualquer outro uso, [...] interessam os aspectos relacionados à responsabilidade civil. Danos que o drone pode causar a terceiros podem ser atribuíveis ao seu proprietário ou detentor [...], na medida em que o drone é um dispositivo cada vez mais sofisticado. (Castells I Marquès, Marina. Drones civiles. In: Navas Navarro, Susana. Inteligencia artificial, Tecnologia, Derecho. Capítulo II. Valencia: Tirant lo Blanc, 2017. p. 79). 
pueden ser atribuibles a su proprietario o poseedor [...], en la medida en que el dron es un aparato cada vez más sofisticado.

Neste cenário, atentando-se ao potencial de colisão entre o uso de drones e a proteção constitucional à privacidade, este artigo tem por objetivo principal analisar a regulação existente no ordenamento jurídico brasileiro acerca da temática, propondo-se, consequentemente, a averiguar seu grau de suficiência na resolução de eventuais violações decorrentes do uso da tecnologia.

Para tanto, revela-se fundamental a consecução dos seguintes objetivos específicos: contextualizar a tecnologia dos drones e seus diversos fins de utilização; discorrer sobre o direito à privacidade, especialmente quanto ao seu status de direito fundamental outorgado pela Constituição Federal de 1988; apresentar o conflito existente entre o uso de drones e a proteção à privacidade, elencando casos que demonstrem tal cenário; e identificar e analisar a regulação existente no Brasil acerca da temática, atentando-se às particularidades desta tecnologia em eventual necessidade de responsabilização na esfera civil.

À vista disso, este artigo divide-se em dois capítulos. No primeiro, discorre-se sobre o direito à privacidade, abordando sua evolução histórica e destacando o caráter de direito fundamental outorgado pela Constituição Federal de 1988; em seguida, apresenta-se a tecnologia dos drones, atentando-se à sua popularização no meio civil e, por consequência, à sua utilização indevida como ferramenta para violação de direitos. 0 capítulo seguinte, por sua vez, é destinado à análise da regulação brasileira sobre drones, expondo-se os principais pontos da legislação existente; assim, são abordados especialmente os aspectos regulatórios relacionados à violação da privacidade, notadamente no que diz respeito aos instrumentos de resolução de tais ilícitos.

Aspira-se, com o presente estudo, contribuir para o conhecimento e enfrentamento de um fenômeno de extrema relevância para o presente e para o amanhã. Como dito por Andre Villar 
Gomez ${ }^{7}$, se há algo que a sociedade espera da academia, é que ela a ajude a fazer escolhas certas sobre o futuro. Confrontar o problema dos drones, especialmente no que tange à proteção do direito à privacidade, é medida inescusável. Afinal, a constante vigilância estatal do Big Brother, personagem clássico criado por George Orwell em "1984", parece estar sendo transposta, pouco a pouco, aos arbítrios individuais do homem moderno.

\section{DRONES $\boldsymbol{X}$ PRIVACIDADE: UM CONFLITO EM ASCENSÃO}

\subsection{A QUARTA REVOLUÇÃO INDUSTRIAL E O DIREITO DE SER DEIXADO EM PAZ \\ O filósofo Aristóteles, há cerca de 2300 anos, já definia o} homem como um animal social, carente e imperfeito, que busca no próximo e na comunidade a sua plenitude ${ }^{9}$. Contudo, sabe-se que a partir desta indispensável interação entre os indivíduos e sua consequente organização em sociedade, surge, diametralmente, a necessidade de se demarcar limites, estabelecendo-se o desejo por um espaço particular alheio à convivência coletiva.

Tal anseio, apesar de acompanhar o homem desde o momento em que passou a viver em comunidade, por certo foi tomando maior relevância política à medida que as relações interpessoais se desenvolveram, fazendo-se necessário, em dado momento da história, que o desejo se tornasse direito. Assim, em 1890, os juristas americanos Samuel Warren e Louis Brandeis publicaram um artigo, na Harvard Law Review, no qual sustentaram que a

7 VILLAR GOMEZ, Andre. Pesadelo high-tech: a quarta revolução industrial e o fim do mundo que conhecemos. Revista Libertas, v. 17. Juiz de Fora: 2017. p. 9.

8 ORWELL, George. 1984. Tradução de Alexandre Hubner e Heloisa Jahn. São Paulo: Companhia das Letras, 2009.

9 ARISTÓTELES. Política. Traduzido por Roberto Leal Ferreira. São Paulo: Martins Fontes, 2002. 
ocorrência de transformações sociais, políticas e econômicas, com destaque à criação de novos inventos, a exemplo da fotografia, estariam contribuindo para a violação de um direito fundamental das pessoas, o qual denominaram de right to privacy ${ }^{10}$. Os autores, utilizando-se da expressão cunhada por Thomas McIntyre Cooley em $1879^{11}$, definiram a privacidade como o direito de ser deixado em paz (the right to be let alone), por meio do qual seria assegurada a cada indivíduo a faculdade de compartilhar, ou não, informações a respeito de sua vida privada ${ }^{12}$.

Transcorrido pouco mais de um século da publicação de Warren e Brandeis, o direito à privacidade consolidou-se pelo mundo, estando consagrado em quase todas as constituições modernas ${ }^{13}$. Relativamente a sua definição, contudo, não existe consenso doutrinário. Para Hyman Gross, o conceito está infectado de ambiguidades perniciosas ${ }^{14}$. Segundo Arthur Miller, a privacidade é difícil de definir porque é notadamente vaga e evanescente ${ }^{15}$. Ao longo da história, filósofos, sociólogos e escritores dedicaram parte de seus estudos ao tema. John Locke, em seu "Segundo tratado sobre o governo civil", conceituou a privacidade como uma liberdade de autonomia da pessoa para dispor, como bem entender, de seus atos, de seus bens, e de tudo

10 BRANDEIS, Louis D. WARREN, Samuel D. The right to privacy. Harvard Law Review, v. 4, n. 5, dec. 15, 1890.

11 COOLEY, Thomas McIntyre. A treatise on the law of torts, or the wrongs which arise independent of contract. Chicago: Callaghan and Company, 1879. Disponível em: http://www.hathitrust.org. Acesso em 21 de mai. 2018.

12 BRANDEIS, Louis D. WARREN, Samuel D. The right to privacy. Harvard Law Review, v. 4, n. 5, dec. 15, 1890. p. 216.

13 CORREIA, Pedro Miguel Alves Ribeiro. JESUS, Inês Oliveira Andrade de. o lugar do conceito de privacidade numa sociedade cada vez mais orwelliana. Rev. Direito, Estado e Sociedade, n. 43, p. 135 a 161. Lisboa: 2013, p. 138.

14 GROSS, Hyman. Privacy - Its Legal Protection. New York: Oceana, 1964, p. 23.

15 MILLER, Arthur. The Assault on Privacy. Ann Arbor: University of Michigan Press, 1971, p. 320. 
quanto lhe pertença ${ }^{16}$. John Stuart Mill, em sua obra denominada "A Liberdade", sustentou que os aspectos que só dizem respeito ao indivíduo são absolutamente independentes, resultando ser o indivíduo soberano sobre si, seu corpo e sua mente ${ }^{17}$.

Na perspectiva de consagração internacional promovida especialmente pela Declaração Universal dos Direitos Humanos de $1948^{18}$, o ordenamento jurídico brasileiro, notadamente através da Constituição Federal de 1988, conferiu à privacidade caráter de direito fundamental - espécie de norma positivada que, por sua importância axiológica, fundamenta e legitima todo o ordenamento jurídico ${ }^{19}$. Deste modo, prevê a Carta Magna Brasileira ${ }^{20}$ em seu artigo $5^{\circ}$, inciso $\mathrm{X}$ :

São invioláveis a intimidade, a vida privada, a honra e a imagem das pessoas, assegurado o direito a indenização pelo dano material ou moral decorrente de sua violação.

Como se observa, a Constituição Federal protege a privacidade, enquanto gênero, ao reconhecer como invioláveis a vida privada, a intimidade, a honra e a imagem das pessoas. Nesse sentido, pois, é o ensinamento de Alexandre de Moraes ${ }^{21}$ :

16 LOCKE, John. Segundo tratado sobre o governo civil: ensaio sobre a origem, os limites e os fins verdadeiros do governo. Petrópolis: Vozes, 1999.

17 MILL, John Stuart. A liberdade. 1 ed. São Paulo: Martins Fontes, 2000.

18 Artigo 12: "Ninguém será sujeito a interferências na sua vida privada, família, lar ou na sua correspondência, nem a ataque à sua honra e reputação. Toda Pessoa tem direito à proteção da lei contra tais interferências ou ataques". Assembleia Geral da ONU. (1948). Declaração Universal dos Direitos Humanos (217 [III] A). Paris. Disponível em: http://www.un.org/ en/universal-declaration-human-rights/. Acesso em 18 de out. de 2018.

19 MARMELSTEIN, George. Curso de direitos fundamentais - 5. Ed. São Paulo: Atlas, 2014. p. 24.

20 BRASIL. Constituição (1988). Constituição da República Federativa do Brasil. Brasília, DF: Senado Federal: Centro Gráfico, 1988. 292 p.

21 MORAES, Alexandre de. Direito Constitucional. 24. a edição. São Paulo: Atlas, 2009, p. 53. 
Os direitos à intimidade e à própria imagem formam a proteção constitucional à vida privada, salvaguardando um espaço íntimo intransponível por intromissões ilícitas externas. A proteção constitucional consagrada no inciso $\mathrm{X}$ do art. $5^{\circ}$ refere-se tanto a pessoa física quanto a pessoas jurídicas, abrangendo, inclusive, a proteção à própria imagem frente aos meios de comunicação em massa.

Por sua vez, o Código Civil de $2002^{22}$ internalizou o instituto da inviolabilidade da vida privada, dispondo, em seu artigo 21 , que o juiz, a requerimento do interessado, deverá tomar as providências necessárias para impedir ou fazer cessar ato contrário à norma. Assim, em resumo, eventual violação à privacidade, em qualquer de suas espécies, deve assegurar ao indivíduo prejudicado, por meio de acesso ao Poder Judiciário, o direito à indenização pelo dano material ou moral decorrente, consoante estabelece o texto legal. Trata-se, portanto, de tutela indispensável ao exercício da cidadania, garantindo-se proteção contra atentados indevidos e também uma esfera de gestão das próprias informações ${ }^{23}$.

Hodiernamente, com o advento de novas tecnologias, o direito à privacidade vem sendo progressivamente vulnerabilizado. 0 fenômeno do desenvolvimento tecnológico experienciado pela sociedade moderna, na visão de muitos especialistas, dentre os quais se destaca Klaus Schwab, deve ser compreendido como a quarta revolução industrial ${ }^{24}$. Frente a este cenário, inclusive, o

22 BRASIL. Código Civil Brasileiro. Lei no 10.406, de 10 de janeiro de 2002. Legislação Federal. Disponível em: http://www.planalto.gov.br/ccivil_03/ Leis/2002/l10406.html. Acesso em: 12 jun. 2018.

23 CANTALI, Fernanda Borghetti. Direitos da personalidade: disponibilidade relativa, autonomia privada e dignidade humana. Porto Alegre: Livraria do Advogado Editora, 2009. p. 199.

24 SCHWAB, Klaus. The Fourth Industrial Revolution: What It Means and How to Respond. Foreign Affairs, Dez. 2015. Disponível em: https://www. foreignaffairs.com/articles/2015-12-12/fourth-industrial-revolution. Acesso em: 23 jul. 2018. 
instituto da privacidade ganhou amplitude em relação ao seu conceito tradicional. Observa-se, nesse sentido, o ensinamento de Fernanda Borghetti Cantali ${ }^{25}$ :

Atualmente, por impulso da doutrina européia, a privacidade passou a ser encarada de forma mais ampla, para além do direito negativo; é também direito ativo: as pessoas têm o direito de controlar a circulação de suas informações pessoais. Trata-se da gestão das próprias informações.

O desafio atual da privacidade, neste cenário, é o de se reinventar numa sociedade da informação e inserida em uma nova revolução tecnológica. Big data, internet das coisas e vigilância são termos cada dia mais comuns, e originam também as grandes preocupações atuais acerca do instituto ${ }^{26}$. Com tantos meios de monitoramento e vigilância, é cada vez mais difícil ficar ou se sentir só ${ }^{27}$.

Dentre as potenciais ameaças modernas à privacidade, notadamente no campo da vigilância, destaca-se a tecnologia dos drones, aeronaves não tripuladas comandadas à distância por seres humanos. Quando utilizada de maneira negativa, esta tecnologia se revela uma grande ferramenta de violação da privacidade. É o que será demonstrado nos parágrafos seguintes.

25 CANTALI, Fernanda Borghetti. Direitos da personalidade: disponibilidade relativa, autonomia privada e dignidade humana. Porto Alegre: Livraria do Advogado Editora, 2009. p. 197.

26 CAMPOS PEIXOTO, Erick Lucena. EHRHARDT JÚNIOR, Marcos. Breves notas sobre a ressignificação da privacidade. Revista Brasileira de Direito Civil. Belo Horizonte, v. 16, p. 35-56, abr./jun. 2018, p. 55.

27 GOULART, Guilherme. Condicionamento, liberdade e privacidade: compreendendo as novas tecnologias por meio do 'Admirável Mundo Novo'. Revista Diálogos do Direito, v. 4, n. 6, Jul/2014. 


\subsection{GAME OF DRONES: CONSEQUENCIAS DE UMA POPULA- RIZAÇÃO RECENTE}

Drone, termo originado nos Estados Unidos da América, é a expressão popular globalmente utilizada para designar toda e qualquer aeronave não tripulada comandada à distância por seres humanos. 0 termo, que significa "zangão" na língua portuguesa, foi cunhado em razão do som peculiar emitido pelas aeronaves durante o voo, que se assemelha ao zumbido produzido pelo inseto.

A origem dos drones remonta ao século XIX, quando os soldados austríacos, para atacar alvos em Veneza, carregavam explosivos em balões sem tripulantes. Em 1989, Nikola Tesla já havia registrado uma patente, denominada Method Of And Apparatus For Controlling Mechanism of Moving Vessels or Vehicles, na qual alertara sobre a capacidade de destruição ilimitada desta tecnologia, prevendo seu potencial de utilização como armamento bélico ${ }^{28}$.

Com efeito, as previsões de Tesla se concretizaram. A partir de 1980, os drones passaram a ser utilizados predominantemente para fins militares, por iniciativa do exército norte-americano. A tecnologia é, desde então, um dos principais instrumentos de estratégia militar do país, sendo utilizada principalmente em ataques aéreos ao Paquistão ${ }^{29}$.

Atualmente, o modelo característico de drone possui um corpo preferencialmente pequeno (usualmente fabricado com matéria leve), hélices, e, de acordo com o propósito de uso, uma câmera integrada - que pode captar imagens até mesmo em alta resolução. As aeronaves possuem peso variado entre dezenas de gramas e centenas de quilos.

28 TESLA, Nikola. Method of and apparatus for controlling mechanism of moving vessels or vehicles. Pat. 68.809. New York: 1898. Disponível em: https://patents.google.com/patent/US613809A/en. Acesso em: 07 ago. 2018.

29 GHOSH, Bobby. THOMPSON, Mark. The CIA's Silent War in Pakistan. Time. Washington: 2009. Disponível em: http://content.time.com/time/magazine/ article/0,9171,1900248,00.html. Acesso em: 11 ago. 2018. 
Imagem 1 - Drone moderno

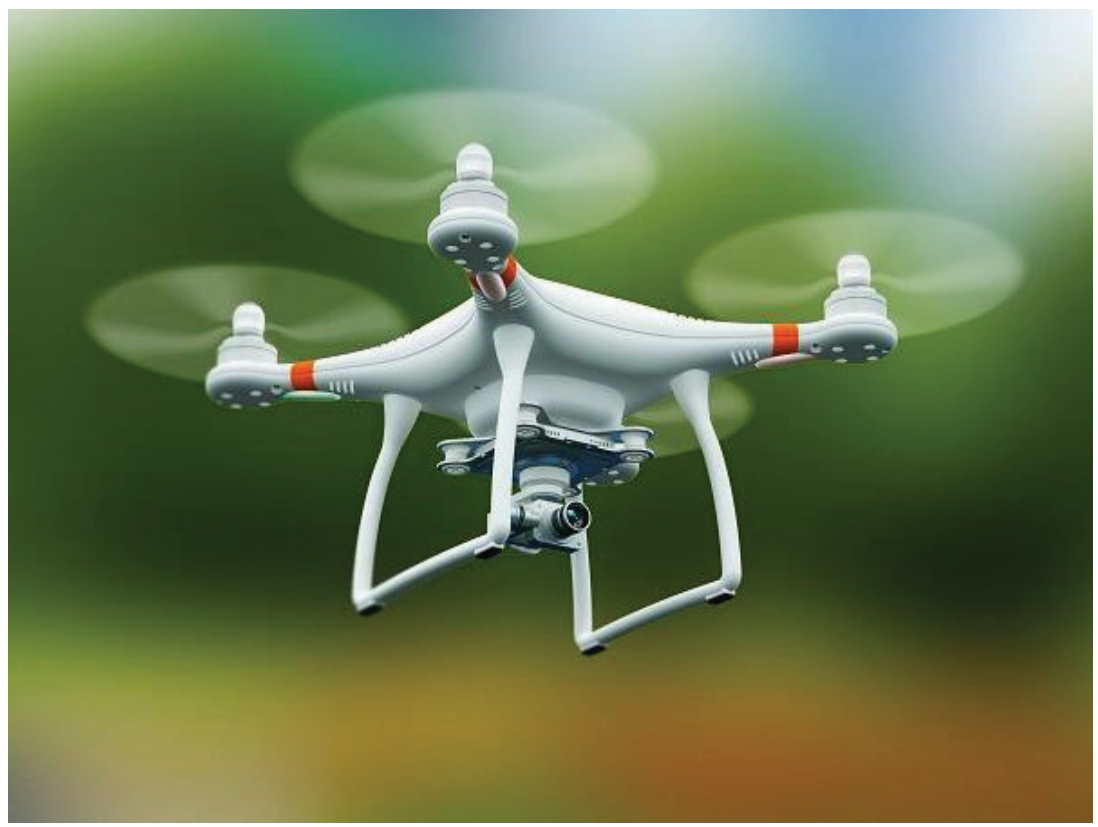

Fonte: Times Now News ${ }^{30}$.

Hodiernamente, os drones se popularizaram no meio civil, de modo que são utilizados para os mais diversos fins. Desde o monitoramento ambiental e de trânsito, até mesmo para a recreação, as aeronaves possuem grande utilidade, por exemplo, nas coberturas fotográficas de eventos, entregas de comida, pulverizações agrícolas, mapeamentos, dentre outros cenários de aplicação. 0 gráfico a seguir, que expressa, em azul, o número de pesquisas pelo termo "drones" realizadas na ferramenta mundial de busca na internet da Google, e, em vermelho, a busca por "veículos aéreos não tripulados", demonstra o processo de popularização das

30 Disponível em: https://www.timesnownews.com/india/article/aviation-ministry-drone-police-draft-flying-drones-to-be-legal-illegal-india-from-december-1-this-year-2018-cameras-penalty-law/275830. Acesso em: 13 ago. 2018. 
aeronaves. Esse fenômeno tem como causas principais a redução no custo de aquisição do produto, bem como o crescimento nos níveis de autonomia de voo, o que facilita seu manuseio ${ }^{31}$.

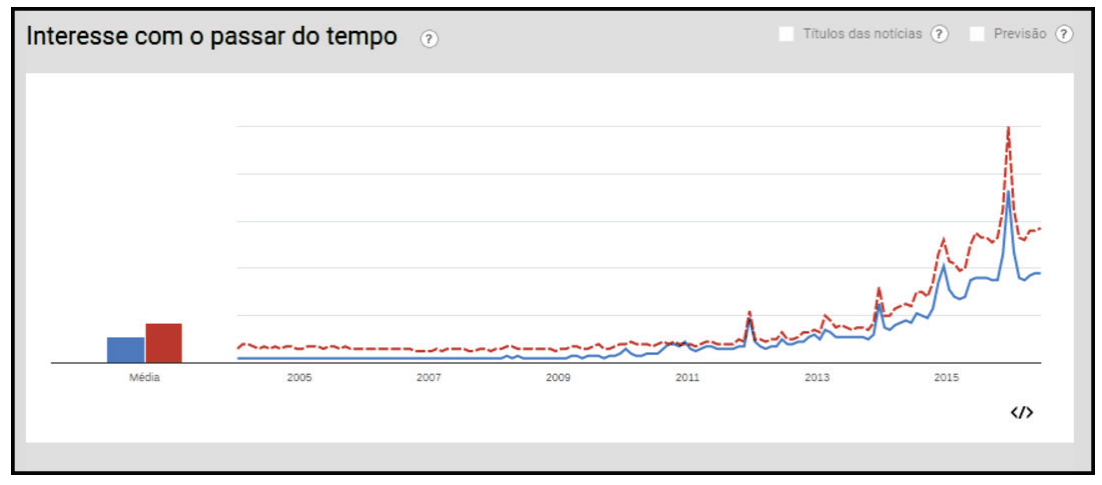

Fonte: Google Trends ${ }^{32}$.

Contudo, a exemplo de qualquer tecnologia, os drones passaram a ser utilizados também de maneira negativa, notadamente como ferramenta de violação da privacidade. Isso porque, em razão de normalmente possuírem uma câmera integrada, estas aeronaves são empregadas como ferramenta para a captura de fotos e vídeos de terceiros, adentrando desmedidamente em sua esfera privada. Atuam, neste cenário, como um olho que tudo vê, com câmeras que filmam, gravam e vigiam o inimigo, que se torna apenas um alvo sem chance de resposta imediata, em uma ação unilateral e unidimensional ${ }^{33}$.

Neste cenário, vários episódios concretos de violação da privacidade mediante o uso da tecnologia dos drones vêm ganhando

31 MATTOS, Nelson. A popularização dos drones. Disponível em: https:// gauchazh.clicrbs.com.br/opiniao/noticia/2015/11/nelson-mattos-a-popularizacao-dos-drones-4917336.html. Acesso em: 12 ago. 2018.

32 Disponível em: https://trends.google.com.br/trends/ explore?date=2006-01-01\%202015-01-01\&geo=BR\&q=drones. Acesso em: 17 ago. 2018.

33 CAMERANO, Ana Cláudia Santos. Novas ameaças e o advento dos drones: a ótica brasileira. Artigo científico. Universidade Federal de Santa Catarina: 2015. Disponível em: https://www.defesa.gov.br/arquivos/ensino_e_pesquisa/defesa_academia/cadn/artigos/xii_cadn/novas_ameacas.pdf. Acesso em: 24 jul. 2018. 
destaque nos noticiários, como será demonstrado a seguir. De tais ações ilícitas, contudo, não são vítimas apenas as celebridades, nada obstante se reconheça que, em razão de sua condição de pessoa pública, são alvos mais visados e ganham maior repercussão nas mídias. 0 fato é que, dentre os diversos casos noticiados, muitos dizem respeito a violações da privacidade de pessoas não-públicas, de modo que a preocupação com os drones não se restringe exclusivamente ao âmbito dos famosos.

Em agosto de 2017, um drone sobrevoou a mansão da modelo Gisele Bündchen e do atleta Tom Brady, na cidade de Boston, nos EUA. Os muros altos e as câmeras de segurança da residência, avaliada em cerca de $\mathrm{R} \$ 160$ milhões, não foram suficientes para impedir que a aeronave fotografasse o casal em um momento de extrema intimidade na piscina ${ }^{34}$.

Imagem 2 - Drone flagra intimidade de Gisele Bundchen e Tom Brady

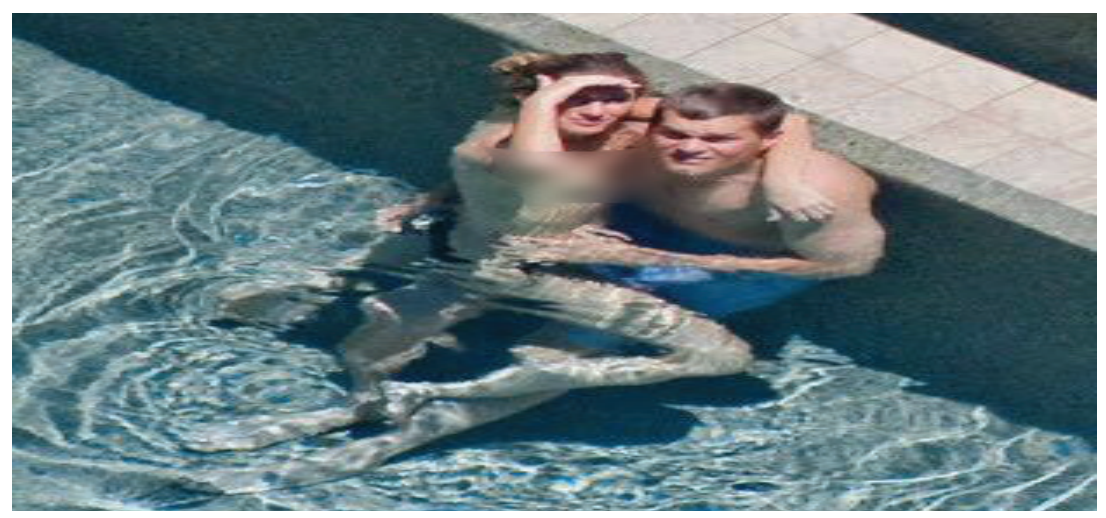

Fonte: Página Brazil ${ }^{35}$

34 JORNAL EXTRA ONLINE. Drone sobrevoa mansão e flagra Gisele Bundchen em momento íntimo com o marido. Disponível em: https://extra.globo.com/ famosos/drone-sobrevoa-mansao-flagra-gisele-bundchen-em-momento-intimo-com-marido-21698916.html. Acesso em: 13 de abr. 2018.

35 Disponível em: https://paginabrazil.com/supostas-imagens-de-gisele-bunchen-fazendo-sexo-com-marido-na-piscina-circulam-na-web-veja/. Acesso em: 13 de abr. 2018. 
Outro episódio que ganhou destaque nos noticiários no ano de 2017, especialmente no âmbito do jornalismo esportivo, foi o caso envolvendo o clube de futebol Grêmio Football Porto-Alegrense. Em novembro, quando a equipe se preparava para disputar a partida final da Copa Libertadores da América, torneio continental de futebol, a rede de televisão ESPN Brasil publicou uma matéria investigativa, de autoria da jornalista Gabriela Moreira, afirmando que a instituição havia utilizado drones, durante toda a temporada, com o intuito de espionar os treinamentos dos rivais nas competições que disputava ${ }^{36}$.

Imagem 3 - Jornalistas comentam episódio sobre drones utilizados pelo Grêmio

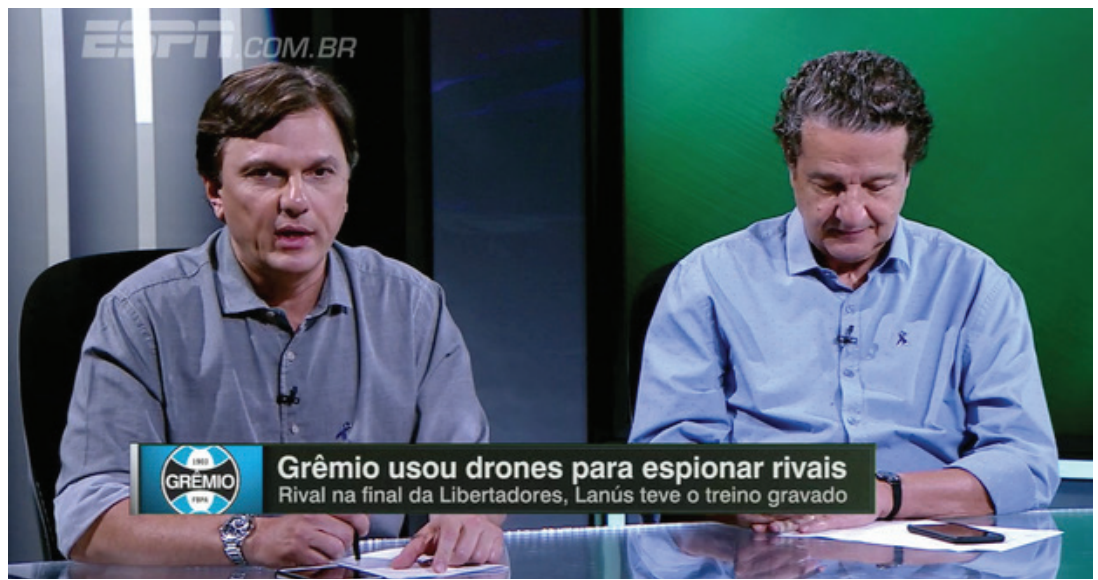

Fonte: ESPN Brasil ${ }^{37}$.

Conforme já registrado, a preocupação com as aeronaves não tripuladas atinge toda a sociedade civil, não se restringindo exclusivamente à esfera privada das pessoas públicas. É o que atestam, dentre tantos, especialmente dois episódios concretos.

36 MOREIRA, Gabriela. ESPN. Exclusivo: Grêmio usou drone para espionar rivais durante o ano; veja flagra em treino do Lanús. Disponível em: http://www.espn.com.br/noticia/744582_exclusivo-gremio-usou-drone-para-espionar-rivais-durante-o-ano-veja-flagra-em-treino-do-lanus. Acesso em: 11 de mar. 2018.

37 Disponível em: http://www.espn.com.br/video/744734_mauro-elogia-nucleo-de-analises-do-gremio-mas-pondera-sobre-uso-de-drone-e-cobra-resposta-de-tecnicos-espionados. Acesso em: 14 de mar. 2018. 
Em junho de 2017, na cidade do Rio de Janeiro, uma mulher teve o quarto invadido por um drone, comandado por seu vizinho. A vítima relatou que se preparava para dormir quando, em função do som peculiar e da luminosidade advinda do aparelho, percebeu a presença da aeronave, que pairava em frente à janela do seu quarto ${ }^{38}$. Por sua vez, no ano de 2014, um drone flagrou uma mulher tomando banho de sol no telhado de um prédio, na Eslováquia. A gravação, que circulou pela internet, mostra que a jovem filmada, percebendo a presença da aeronave, ainda tenta acertá-la com uma vassoura ${ }^{39}$.

Imagem 4 - Homem espiona vizinha utilizando drone

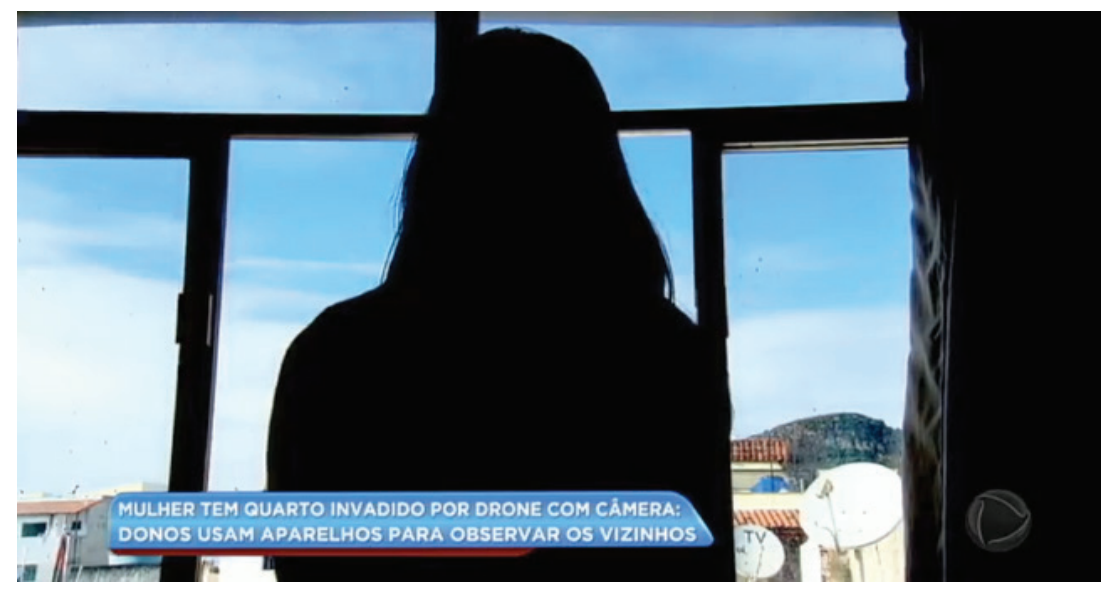

Fonte: Record $\mathrm{TV}^{40}$.

38 RECORD TV. Homem usa drone para espionar vizinha. Disponível em: http://recordtv.r7.com/balanco-geral/videos/homem-usa-drone-para-espionar-vizinha-21102018. Acesso em: 17 de abr. 2018.

39 G1. Drone flagra mulher de topless pegando sol em telhado de edifício. Disponível em: http://g1.globo.com/planeta-bizarro/noticia/2014/10/ drone-flagra-mulher-de-topless-pegando-sol-em-telhado-de-edificio.html. Acesso em: 17 de abr. 2018.

40 Disponível em: http://recordtv.r7.com/balanco-geral/videos/homem-usa-drone-para-espionar-vizinha-21102018. Acesso em: 17 de abr. 2018. 
Imagem 5 - Drone flagra mulher tomando banho de sol em telhado

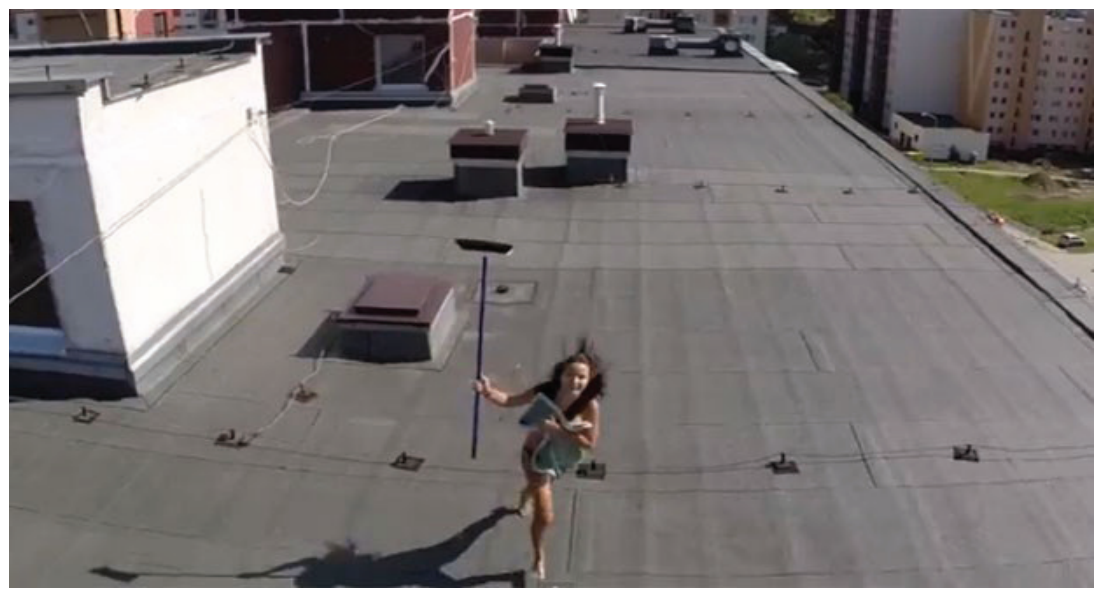

Fonte: $\mathrm{G} 1^{41}$.

À vista deste cenário atual de utilização do drone como ferramenta de violação da privacidade, bem ainda considerando o crescente processo de popularização da tecnologia, revela-se fundamental averiguar a regulação existente no ordenamento jurídico brasileiro acerca destas aeronaves, a fim de que se verifique seu grau de suficiência frente a episódios concretos de práticas ilícitas na esfera civil. Assinala-se, por oportuno, que nada obstante se reconheça a extensão da problemática dos drones à esfera estatal, notadamente no que tange à sua utilização pelas forças policiais ${ }^{42}$, o presente artigo limita-se a analisar a regulação brasileira com vistas aos problemas de violação da privacidade no âmbito civil privado, consoante avistar-se-á no capítulo seguinte.

41 Disponível em: http://g1.globo.com/planeta-bizarro/noticia/2014/10/ drone-flagra-mulher-de-topless-pegando-sol-em-telhado-de-edificio.html. Acesso em: 17 de abr. 2018.

42 SENADO NOTÍCIAS. Senado aprova uso de drones por forças policiais. Disponível em: https://www12.senado.leg.br/noticias/audios/2017/12/ senado-aprova-uso-de-drones-por-forcas-policiais. Acesso em: 19 de mai. 2018. 


\section{A REGULAÇÃO BRASILEIRA SOBRE DRONES}

\subsection{DIVISÃO REGULATÓRIA E O RBAC-E N $N^{\circ} 94$}

No Brasil, os drones são atualmente regulamentados por três órgãos: Agência Nacional de Telecomunicações (ANATEL), Departamento de Controle do Espaço Aéreo (DECEA), e Agência Nacional de Aviação Civil (ANAC).

Compete à ANATEL, de início, homologar todos os drones existentes no território nacional. Isso porque, para transmitir imagens, as aeronaves possuem transmissores de radiofrequência em seus controles remotos e, em alguns casos, no próprio veículo aéreo. Deste modo, a agência de telecomunicações busca evitar que os drones interfiram em outros serviços cruciais, a exemplo das comunicações via satélite ${ }^{43}$.

O DECEA, na condição de responsável pelo controle do espaço aéreo brasileiro, é o órgão que regula algumas questões práticas importantes atinentes às operações com drones, como, por exemplo, locais de proibição de voos, altura máxima permitida, condições para a realização das operações, dentre outras ${ }^{44}$.

Por fim, compete à ANAC regular pontos gerais relativos às operações com drones no âmbito civil. Desta forma, é a agência de aviação civil o órgão principal no enfrentamento de questões cruciais relativas às aeronaves, como parâmetros de classificação e registro, e medidas de segurança ${ }^{45}$.

Neste contexto, a Agência Nacional de Aviação Civil editou, em maio de 2017, o Regulamento Brasileiro da Aviação Civil

${ }^{43}$ ANATEL. Drones devem ser homologados para evitar interferências. Disponível em: http://www.anatel.gov.br/institucional/ultimas-noticiass/2-uncategorised/1485-drones-devem-ser-homologados-para-evitar-interferencias. Acesso em: 6 de set. 2018.

44 DECEA. Conheça as orientações. Disponível em: https://www.decea.gov. br/drone/. Acesso em: 7 de set. 2018.

45 ANAC. Orientações para usuários de drones. Disponível em: http://www. anac.gov.br/assuntos/paginas-tematicas/drones/orientacoes_para_usuarios. pdf. Acesso em: 7 de set. 2018. 
Especial no 94 (RBAC-E 94) ${ }^{46}$, por meio do qual estabelece regras gerais para o uso civil de aeronaves não tripuladas. 0 normativo da ANAC, que desde sua publicação passou a ser a principal regulação nacional sobre o assunto, foi inspirado nas normas internacionais editadas especialmente pela Federal Aviation Administration (FAA), Civil Aviation Safety Authority (CASA) e European Aviation Safety Agency (EASA), autoridades aeronáuticas dos Estados Unidos, Austrália e União Européia, respectivamente ${ }^{47}$.

À vista disso, portanto, revela-se inescusável a análise dos principais pontos abordados pelo RBAC-E no 94 sob uma perspectiva crítica, atentando-se especialmente aos reflexos gerados ao campo da privacidade, seja de maneira direta, seja indiretamente.

\subsubsection{Aspectos gerais}

O Regulamento Brasileiro da Aviação Civil Especial n 94, na condição de principal normatização brasileira sobre drones, aborda os requisitos gerais de competência da ANAC para estas aeronaves. Em seu preâmbulo, registra que o objetivo do regulamento é promover um desenvolvimento sustentável e seguro para o setor, considerando especialmente o atual estágio de desenvolvimento da tecnologia. ${ }^{48}$

De início, o texto regulatório demarca sua aplicabilidade, restringindo-a exclusivamente às aeronaves não tripuladas de uso civil que: $a$ ) possuírem certidão de cadastro, certificado de matrícula brasileiro ou certidão de marca experimental emitidos

46 ANAC. Regulamento Brasileiro da Aviação Civil Especial (RBAC-E n 94). Aprovado pela Resolução ${ }^{\circ}$ 419, de 2 de maio de 2017.

47 ANAC. Orientações para usuários de drones. Disponível em: http://www. anac.gov.br/assuntos/paginas-tematicas/drones/orientacoes_para_usuarios. pdf. Acesso em: 7 de set. 2018. p. 3.

48 ANAC. Regulamento Brasileiro da Aviação Civil Especial (RBAC-E n 94). Aprovado pela Resolução ${ }^{\circ}$ 419, de 2 de maio de 2017. p. 3. 
pela ANAC; e/ou $b$ ) operarem em território brasileiro ${ }^{49}$. Extrai-se, daí, que as aeronaves militares não estão sujeitas à regulamentação da ANAC.

No que diz respeito à classificação dos drones, o regulamento cria duas categorias distintas de acordo com o propósito de utilização do equipamento. Assim, equipara a aeromodelo toda aeronave não tripulada com finalidade de recreação, ao passo que denomina de "Aeronaves Remotamente Pilotadas" (Remotely-Piloted Aircraft - RPA) as aeronaves com finalidades diversas da recreativa ${ }^{50}$.

Por fim, o normativo encerra sua parte geral dispondo que a fiscalização dos drones será realizada pelos órgãos de segurança pública, bem como alertando para o fato de que eventuais irregularidades serão passíveis de sanções previstas no Código Brasileiro de Aeronáutica (Lei no 7.565/86) e nas demais legislações cíveis e penais existentes no ordenamento pátrio ${ }^{51}$.

\subsubsection{Aspectos operacionais de segurança}

De uma leitura do RBAC-E $\mathrm{n}^{\circ}$ 94, depreende-se facilmente que o foco do texto regulatório está nas questões relacionadas à segurança física dos civis expostos às operações com drones.

Inicialmente, o normativo impõe que nenhuma aeronave poderá sobrevoar a menos de trinta metros horizontais de pessoas não envolvidas e não anuentes com a operação ${ }^{52}$. Após, dispõe que todos os pilotos remotos e observadores de RPA - excetuando-se, por conseguinte, as operações recreativas (equiparadas a

49 ANAC. Regulamento Brasileiro da Aviação Civil Especial (RBAC-E n 94). Aprovado pela Resolução ${ }^{\circ} 419$, de 2 de maio de 2017. p. 4.

50 ANAC. Regulamento Brasileiro da Aviação Civil Especial (RBAC-E n 94). Aprovado pela Resolução ${ }^{\circ}$ 419, de 2 de maio de 2017. p. 4.

51 ANAC. Regulamento Brasileiro da Aviação Civil Especial (RBAC-E $\mathbf{n}^{\circ}$ 94). Aprovado pela Resolução ${ }^{\circ} 419$, de 2 de maio de 2017. p. 7.

52 ANAC. Regulamento Brasileiro da Aviação Civil Especial (RBAC-E n 94). Aprovado pela Resolução ${ }^{\circ}$ 419, de 2 de maio de 2017. p. 4. 
aeromodelismo) - devem possuir mais de 18 anos de idade, bem como licença e habilitação para o voo, concedidas pela $\mathrm{ANAC}^{53}$.

Em sequência, nomeadamente em sua "Subparte B", o RBAC-E no 94 proíbe o transporte de pessoas e animais em aeronaves não tripuladas e, por fim, veda qualquer operação autônoma de aeronaves não tripuladas, ou seja, proíbe qualquer voo realizado sem o controle remoto de um humano ${ }^{54}$.

Neste cenário, registra-se, o regulamento da ANAC se destaca de maneira positiva, estabelecendo, na medida de sua preocupação com a segurança física das pessoas e animais expostos às operações com drones, regramentos necessários e coerentes, na linha adotada pelas legislações internacionais. Contudo, a agência reguladora peca ao não estender o critério de idade mínima de pilotagem também aos aeromodelos, de modo que abre margem à prática de voos imprudentes por parte de crianças e adolescentes, correndo-se o risco desnecessário de danos físicos e à privacidade advindos destas operações.

\subsubsection{Critério de registro}

0 aspecto mais importante a ser averiguado no normativo da ANAC é o que diz respeito à necessidade de registro das aeronaves não tripuladas. Isso porque, em uma perspectiva lógica, infere-se que é por meio do ato registral que os drones, e consequentemente seus controladores, saem do anonimato, permitindo sua identificação em eventuais episódios de violações a direitos.

Em sua "Subparte D", o RBAC-E no $94^{55}$ dispõe que qualquer drone, seja RPA ou aeromodelo, deve ser cadastrado junto à ANAC e vinculado a uma pessoa (física ou jurídica) no Brasil, que será a

53 ANAC. Regulamento Brasileiro da Aviação Civil Especial (RBAC-E n 94). Aprovado pela Resolução $n^{\circ} 419$, de 2 de maio de 2017. p. 6.

54 ANAC. Regulamento Brasileiro da Aviação Civil Especial (RBAC-E n 94). Aprovado pela Resolução n 419 , de 2 de maio de 2017. p. 8.

55 ANAC. Regulamento Brasileiro da Aviação Civil Especial (RBAC-E n 94). Aprovado pela Resolução ${ }^{\circ}$ 419, de 2 de maio de 2017. p. 11. 
responsável legal pela aeronave. 0 parágrafo (d), porém, excetua a regra de registro ao dispor que "as aeronaves não tripuladas de peso máximo de decolagem de até 250 gramas não precisam ser cadastradas junto à ANAC ou identificadas". Em resumo, portanto, só estão obrigados ao registro, no Brasil, os drones com peso superior a 250 gramas.

Sabe-se, contudo, que a indústria dos drones, e, de um modo geral, de tecnologia, está em constante aperfeiçoamento. John Horgan, em artigo publicado ainda no ano de 2013, já apontava para a tendência de evolução dos drones para objetos cada vez menores, facilitando sua utilização para fins de vigilância ${ }^{56}$. Suas previsões, em verdade, já se concretizaram.

Hoje, uma rápida pesquisa na internet revela que já existem disponíveis, no mercado, diversos modelos de drones com peso inferior a 250 gramas - a maior parte deles a preços bastante acessíveis. Casos, por exemplo, de dois modelos, dentre tantos, encontrados à venda no Brasil: o Mini Drone Cheerson CX-10W e o Hover Camera Passport.

Comercializado nas Lojas Americanas, popular rede de varejo brasileira, ao custo de $\mathrm{R} \$ 319,00$ (trezentos e dezenove reais), o Mini Drone Cheerson CX-10W pesa inacreditáveis 17 gramas. Apesar da baixa qualidade da câmera integrada ao equipamento, que é de apenas 0.3 megapixels de resolução, este pequeno drone transmite imagens em tempo real para aparelho celular com sistema Android ou IOS, sendo controlado também por meio de dispositivo móvel ${ }^{57}$.

56 HORGAN, John. Why drones should make you afraid very afraid. Scientific American, fev. 2013. Disponível em: http://blogs.scientificamerican.com/ cross-check/why-drones-should-make-you-afraid-very-afraid/. Acesso em 17 set. 2018.

57 AMERICANAS.COM. Mini Drone Cheerson Cx10w Com Camera Hd Fpv Wifi. Disponível em: https://www.americanas.com.br/produto/22348498/mini-drone-cheerson-cx10w-com-camera-hd-fpv-wifi. Acesso em: 4 de set. 2018. 
Imagem 6 - Mini Drone Cheerson CX-10W

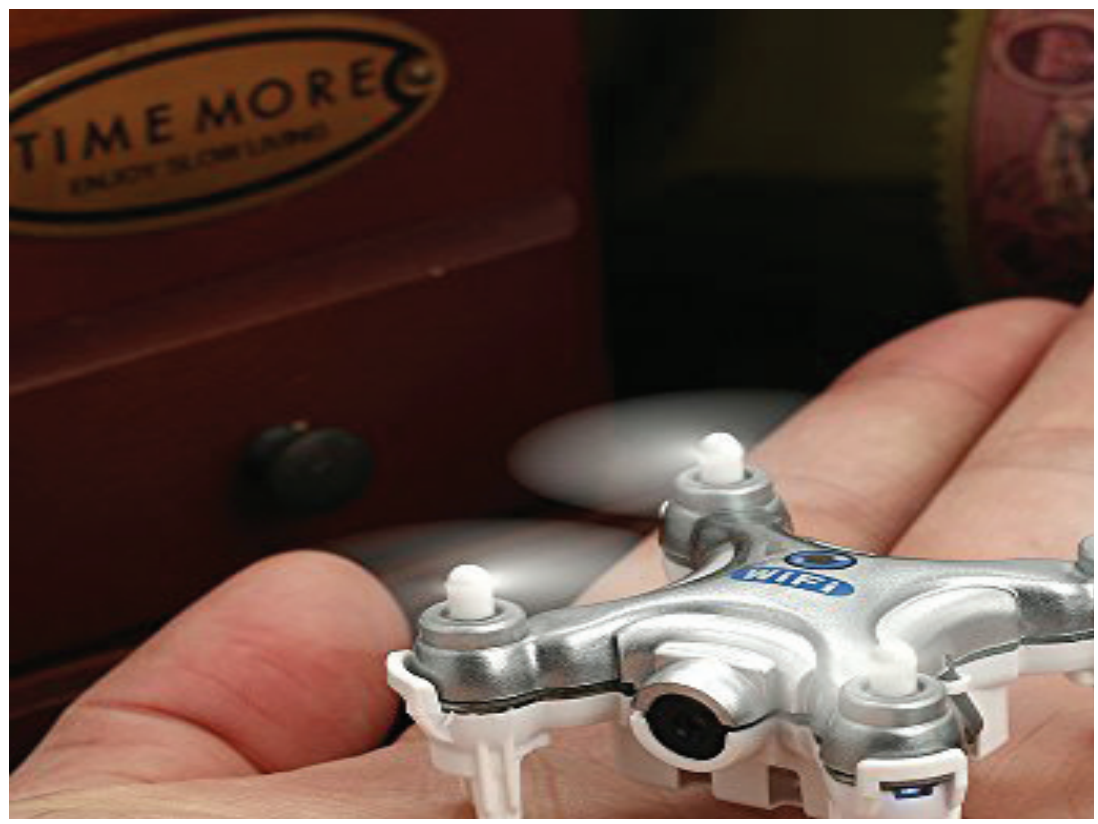

Fonte: YouTube ${ }^{58}$.

Por sua vez, o drone Hover Camera Passport, encontrado à venda no site brasileiro da GearBest ao custo de R\$1478,00 (mil quatrocentos e setenta e oito reais), pesa 242 gramas e consegue capturar imagens e vídeos em 4K (ultra resolução). Além disso, a aeronave destaca-se por ser dobrável e contar com as tecnologias de reconhecimento de corpo/rosto e de controle por gestos ${ }^{59}$.

Não bastasse o cenário atual de desenvolvimento da tecnologia dos drones para se chegar à conclusão de que o critério de peso para registro estabelecido pela ANAC é deveras obsoleto, ainda é possível observar que o prognóstico, por parte da indústria, corrobora muito com tal constatação.

58 Disponível em: https://www.youtube.com/watch?v=nlZBBqqx7gk. Acesso em: 4 de set. 2018.

59 BR.GeARBEST.COM. Hover Camera Passport RC Drone Dobrável de Bolso - PRETO. Disponível em: https://br.gearbest.com/rc-quadcopters/ pp_1058692.html. Acesso em: 4 de set. 2018. 
Imagem 7 - Hover Camera Passport

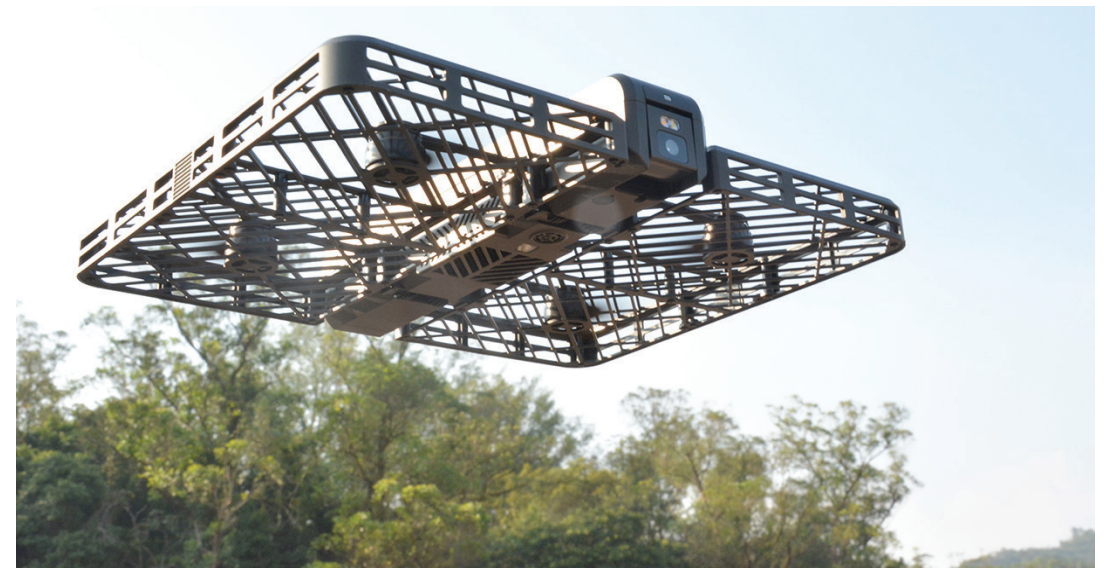

Fonte: Engadget ${ }^{60}$.

A Harvard University e o Massachusetts Institute of Technology (MIT), duas das maiores instituições de ensino do mundo, estão desenvolvendo, em conjunto, projetos de microaeronaves reproduzidas em escala de insetos, a exemplo do RoboBee, um microdrone com a aparência e o tamanho de uma pequena abelha ${ }^{61}$. De igual modo, cientistas japoneses testaram com sucesso, em 2017, a utilização de um "drone-inseto" na polinização artificial de plantas. 0 projeto, contudo, ainda está em desenvolvimento. O próximo passo, segundo os cientistas, é treinar os robôs para que aprendam as rotas de polinização através de GPS e inteligência artificial ${ }^{62}$.

60 Disponível em: https://www.engadget.com/2017/04/12/hover-camera-passport-owner-mode-apple/. Acesso em: 5 de set. 2018.

61 BGR. This robotic bee uses static eletricity to stick to surfaces. Disponível em: https://bgr.com/2016/05/20/harvard-mit-robobee-perching/. Acesso em: 5 de out. 2018.

62 CASTRO, Fábio. ESTADÃO. Cientistas desenvolvem 'drone-inseto’ para fazer polinização. Disponível em: https://ciencia.estadao.com.br/noticias/geral,cientistas-desenvolvem-drone-inseto-para-fazer-polinizacao,70001658819. Acesso em: 13 de out. 2018. 
Imagem 8 - Protótipo do microdrone RoboBee

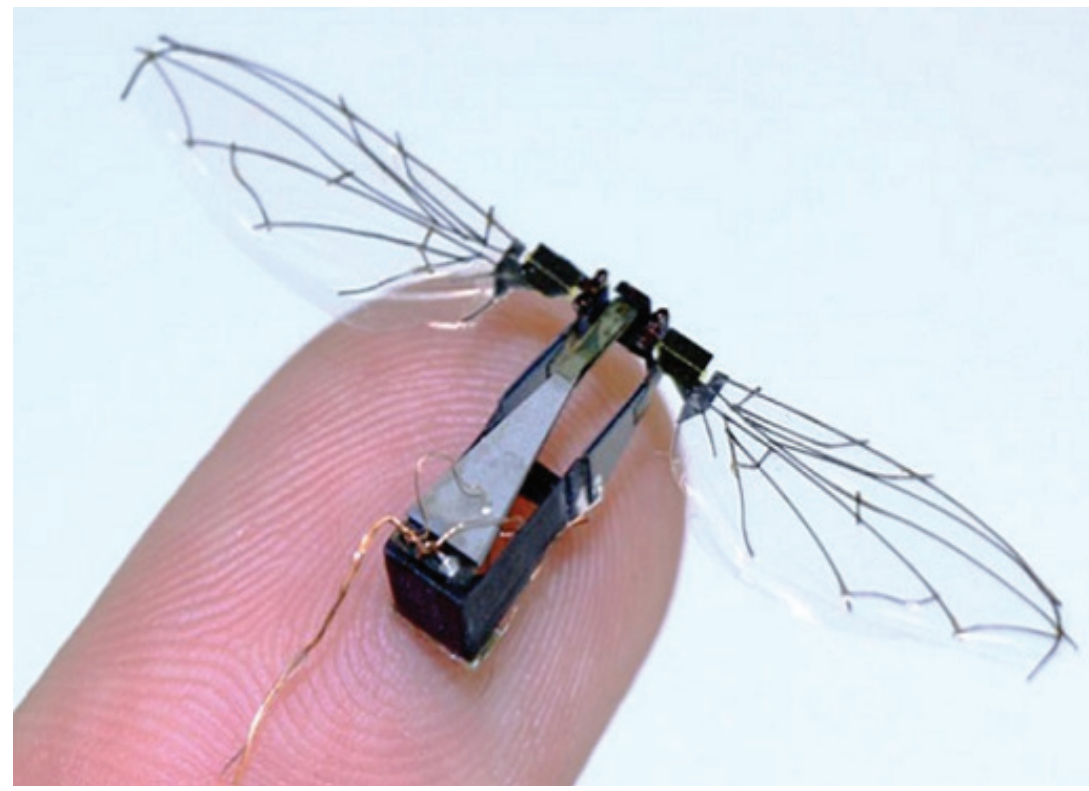

Fonte: $\mathrm{BGR}^{63}$.

Vê-se, portanto, que o critério de peso para registro, na forma estabelecida pela ANAC em seu regulamento, leva em consideração apenas a preocupação com a segurança física das pessoas expostas às operações com drones, porquanto pressupõe que uma aeronave com peso inferior a 250 gramas não teria capacidade de causar maiores danos em eventual queda ou colisão. Contudo, à vista do cenário de redução cada vez maior do tamanho destas aeronaves, irrompe a preocupação com seu registro, notadamente em razão de seu potencial de utilização como ferramenta de violação da privacidade. Assim, até que se evolua na regulação da matéria, estes pequenos drones seguirão, preocupantemente, operando em total anonimato.

${ }^{63}$ Disponível em: https://bgr.com/2016/05/20/harvard-mit-robobee-perching/. Acesso em: 16 de out. 2018. 


\subsubsection{Fiscalização}

Outro ponto de extrema importância na análise da problemática dos drones diz respeito à efetiva fiscalização dos controladores e das operações. Como já mencionado anteriormente, o RBAC-E no 94 atribui aos órgãos de segurança pública tal encargo. Todavia, desde a publicação do regulamento, não foi implementado qualquer sistema de fiscalização destas aeronaves, de modo que, neste cenário permissivo, estudos demonstram que há muitos drones não registrados em operação no território nacional, ainda que se enquadrem na categoria de registro ${ }^{64}$.

Tal situação, porém, não é exclusiva do Brasil. Em artigo publicado no ano de 2014, Roger Clarke já alertara para a dificuldade de implementação de um sistema efetivo de fiscalização dos drones, concluindo que, embora a legislação australiana, objeto do seu estudo, se mostrasse avançada na regulação da matéria, a grande lacuna a ser preenchida dizia respeito diretamente à sua efetiva aplicação ${ }^{65}$.

Com efeito, regular e fiscalizar as operações com aeronaves não tripuladas é uma tarefa complexa e que demanda um grande esforço por parte das autoridades competentes. De todo modo, um bom primeiro passo certamente seria voltar os olhos à regulação internacional da matéria - especialmente à europeia, que se revela sabidamente mais avançada.

A partir da experiência de outros países, portanto, poderão surgir soluções e caminhos a serem trilhados na evolução regulatória tupiniquim. É o que será abordado nos parágrafos seguintes.

${ }^{64}$ GRANEMANN, Emerson. Os desafios da regulamentação do uso de drones no Brasil. 2018. Disponível em: https://droneshowla.com/artigo-os-desafios-da-regulamentacao-do-uso-de-drones-no-brasil/. Acesso em: 20 de out. 2018.

65 CLARKE, Roger. The Regulation of Civilian Drones Impacts on Behavioural

Privacy. Computer Law \& Security Review: 2014. p. 36. 
3.2. A EXPERIÊNCIA INTERNACIONAL SOBRE DRONES E AS PROPOSIÇÕES PARA UMA EVOLUÇÃO REGULATÓRIA NO BRASIL

Quando se pensa na problemática dos drones, o RBAC-E no 94, publicado pela ANAC em maio de 2017, pode parecer prógono. Em verdade, porém, a regulação mundial da matéria iniciou já em 2012, quando a França começou a planejar uma legislação que, três anos mais tarde, culminou no Arrêté du 17 décembre 2015 relatif à l'utilisation de l'espace aérien par les aéronefs qui circulent sans personne à bord ${ }^{66}$. 0 pioneiro decreto francês, dentre outros pontos, destaca-se principalmente ao estabelecer a criação de uma lista com todos os fabricantes de drones, obrigando-os ao registro na Direction Générale de l'Aviation Civile (DGAC), bem ainda ao determinar o cadastro também das empresas e pessoas físicas utilitárias das aeronaves.

Os Estados Unidos da América, por sua vez, publicaram sua primeira regulamentação sobre a matéria em junho de 2016. 0 Summary of small unmaned aircraft rule (part 107) ${ }^{67}$, editado pela Federal Aviation Administration (FAA), além de atentar-se a diversas questões relativas à segurança operacional dos voos, merece destaque no que tange à sua aparente preocupação com a questão da privacidade. Isso porque, embora não regule o modo como os drones reunirão dados sobre pessoas ou bens - o que, via de regra, não é tutelado em nenhum regulamento sobre a matéria -, a agência americana estabeleceu, como parte de uma campanha educacional, o fornecimento, a todos os usuários de drones, de diretrizes de privacidade recomendadas. A conscien-

66 Decreto de 17 de dezembro de 2015 relativo à utilização do espaço aéreo por aeronaves não tripuladas. PARLEMENT FRANÇAIS. Arrêté du 17 décembre 2015 relatif à l'utilisation de l'espace aérien par les aéronefs qui circulent sans personne à bord. France: 2015.

67 Resumo das regras sobre pequenas aeronaves não tripuladas. FEDERAL AVIATION ADMINISTRATION. Summary of small unmaned aircraft rule (part 107). USA: 2016. 
tização é realizada durante o processo de registro da aeronave, por meio do aplicativo móvel da FAA.

Por fim, merece registro a recente aprovação, pelo Parlamento Europeu, da primeira regulamentação sobre drones a nível continental. A legislação foi aprovada em junho de 2018 e ainda necessita da anuência do Conselho da União Européia ${ }^{68}$. 0 normativo é baseado em estudos realizados pelas comissões européias acerca da temática, dentre os quais destacam-se dois documentos: a "Proposta de resolução que contém recomendações à Comissão Jurídica sobre disposições de Direito Civil e Robótica"69 , de janeiro de 2017, e o "Estudo das implicações da utilização civil de drones para a privacidade e para a proteção de dados"70, de junho de 2015. Dentre outros pontos abordados, tais estudos se destacam ao preverem a necessidade de: $a$ ) elucidação do setor dos drones (fabricantes e usuários) acerca de suas obrigações, nomeadamente através de campanhas de conscientização (seminários, informativos, debates públicos, etc); $b$ ) identificação e localização dos drones e proprietários através de GPS; c) criação de um sistema de rastreabilidade e identificação que permita determinar a posição da aeronave em tempo real, durante sua operação.

68 PARLAMENTO EUROPEU. Drones: PE aprova primeiras regras a nível europeu para garantir segurança. 2018. Disponível em: http://www. europarl.europa.eu/news/pt/press-room/20180607IPR05239/drones-pe-aprova-primeiras-regras-a-nivel-europeu-para-garantir-seguranca. Acesso em: 23 de out. 2018.

69 PARlamento EUROPEU. Comissão dos Assuntos Jurídicos. Proposta de resolução que contém recomendações à Comissão Jurídica sobre disposições de Direito Civil e Robótica. 2017. Disponível em: http://www. europarl.europa.eu/sides/getDoc.do?pubRef=-//EP//TEXT+REPORT+A82017-0005+0+DOC+XML+V0//PT. Acesso em: 17 de out. de 2018.

70 PARLAMENTO EUROPEU. Direcção-Geral de Políticas Internas. Estudo das implicações da utilização civil de drones para a privacidade e para a proteção de dados. 2016. Disponível em: http://www.europarl.europa.eu/ RegData/etudes/IDAN/2015/519221/IPOL_IDA(2015)519221_PT.pdf. Acesso em: 18 de out. 2018. 
Atentando-se, assim, ao cenário internacional de regulamentação dos drones, bem ainda considerando o regramento existente hoje no ordenamento jurídico pátrio, propõe-se, neste artigo, visando a evolução regulatória na matéria, três medidas consideradas cruciais para a proteção do direito à privacidade.

De plano, entende-se imprescindível que se extenda a necessidade de registro a todos os modelos de drones, independentemente do peso da aeronave. Isso porque, na linha do que restou demonstrado neste capítulo, o cenário de desenvolvimento da tecnologia, seja atual - com a comercialização de microaeronaves ultraleves - ou futuro - com a redução de tamanho dos drones à escala de insetos -, revela que o critério de peso estabelecido pela ANAC, especialmente considerando o aspecto de proteção à privacidade, é manifestamente inadequado. Assinala-se que tal medida já foi proposta pela Agência Europeia para a Segurança da Aviação (EASA) em parecer enviado à União Europeia no ano de 2017, o que demonstra a preocupação com o problema também no cenário internacional ${ }^{71}$.

De outra banda, propõe-se, como segunda medida, a criação de um mecanismo de registro de todas as vendas de drones realizadas pelos fabricantes, em um primeiro momento, e, após, pelos comerciantes, junto aos órgãos estatais. Nesse registro, sugere-se, haveria a identificação do número de série da aeronave e o nome do comprador, com vistas a evitar o anonimato de eventual drone operando em território nacional. Ademais, poder-se-ia, nesse passo, ser pensado um sistema de responsabilização solidária - entre comprador e vendedor -, na esfera administrativa, em razão do descumprimento de tal registro.

Ainda, uma última medida, que inclusive já foi adotada pelas legislações americana e européia, diz respeito à criação de me-

71 CASTELLS I MARQUÈS, Marina. Drones civiles. In: Navas Navarro, Susana. Inteligencia artificial, Tecnologia, Derecho. Capítulo II. Valencia: Tirant lo Blanc, 2017. p. 77. 
canismos de conscientização do setor de drones acerca de suas obrigações, especialmente em relação aos aspectos de segurança e privacidade. Desta forma, sugere-se a criação de campanhas de elucidação, a realização de seminários e debates públicos, ou até mesmo a obrigatoriedade da conscientização como parte do processo de registro da aeronave, tal como ocorre nos EUA.

\section{CONSIDERAÇÕES FINAIS}

O direito, já destacou certa vez Miguel Reale, é um fenômeno histórico-social constantemente sujeito a variações e intercorrências, fluxos e refluxos no espaço e no tempo ${ }^{72}$. Hoje, trinta anos depois da promulgação da Constituição da República Federativa do Brasil, que consagrou a privacidade como direito fundamental, a evolução científico-tecnológica ameaça pôr em risco este basilar instituto.

Viu-se, no presente artigo, que nada obstante se reconheça o proveito dos drones em diversas aplicações na sociedade civil, a utilização negativa da tecnologia, notadamente como ferramenta de violação da privacidade, já é realidade no cenário brasileiro. Nesse passo, buscou-se analisar a regulação existente no país sobre a matéria, averiguando, por corolário, seu grau de suficiência em eventuais episódios de violação de direitos. Afinal, neste cenário atual de desenvolvimento tecnológico irrefreável, por certo um Estado só resguardará o mínimo de liberdade e igualdade de seus cidadãos se assegurar a eles o direito à privacidade ${ }^{73}$.

As conclusões alcançadas, muito embora se compreenda a natureza hodierna da temática, denotam que a regulação brasileira sobre drones, embora acerte na proteção dos civis expostos às operações de voo, carece de evolução em alguns aspectos não so-

72 REALE, Miguel. Lições preliminares de direito. 27 ed. São Paulo: Saraiva, 2002. p. 14.

73 VIANNA, Túlio Lima. Transparência Pública, Opacidade Privada: o direito como instrumento de limitação do poder na sociedade. Revan: Rio de Janeiro, 2007. p. 197. 
pesados por ocasião de seu planejamento. Isso porque o RBAC-E no 94, que passou a ser a principal normatização sobre o tema no ordenamento jurídico pátrio, debruça-se exclusivamente sobre a perspectiva da segurança operacional das aeronaves, de modo que é possível observar pontos falhos em relação à preocupação com a privacidade, a exemplo do critério de peso para necessidade de registro. Demonstrou-se, pois, que os 250 gramas estipulados como critério pela ANAC, embora razoáveis se considerado o propósito de segurança física adotado pela agência, revelam-se, em verdade, inapropriados no que tange à inquietação com a privacidade, porquanto a tendência da indústria dos drones é de redução, dia após dia, das dimensões das aeronaves.

À vista disso, e atentando-se ao cenário internacional de regulamentação da matéria, foram apresentadas propostas objetivando a evolução regulatória no Brasil. Aventou-se, de início, a necessidade de extensão da obrigatoriedade de registro para todas as classes de aeronaves, independentemente de seu peso. Após, a criação de um mecanismo de cadastro de todas as vendas de drones junto aos órgãos estatais, sugerindo-se a responsabilização solidária por eventual descumprimento. Por fim, sugeriu-se, especialmente considerando a adoção de tal medida pelos EUA e pela União Européia, a implementação de campanhas de conscientização ao setor, seja através de seminários e debates públicos, seja tornando obrigatória a elucidação como parte do processo de registro das aeronaves.

O cenário mundial de regulamentação dos drones é recente, e por certo a crescente popularização destas aeronaves, em razão especialmente da facilidade de acesso à tecnologia estar a cada dia mais consolidada, fará necessária uma evolução regulatória da matéria, principalmente na medida em que os episódios concretos tomarem espaço na sociedade civil. Nesse passo, propõe-se este estudo a servir, pois, se não como parecer, ao menos como alerta para um futuro quase - e já - presente. 
Quando George Orwell escreveu "1984"74, talvez não pudesse imaginar que, pouco mais de meio século depois de sua publicação, a ficção distópica já começaria a adquirir contornos de realidade. As "teletelas", que no romance eram utilizadas como ferramenta de vigilância e controle do governo autoritário do Big Brother, em muito podem ser comparadas aos drones, que já começam a despontar nos céus de quase todo o planeta. Isso porque seu potencial lesivo à privacidade, talvez nunca antes presente em qualquer outra tecnologia, origina uma assombrosa constatação: a de que o Big Brother, projetado por Orwell em um governante tirano e totalitário, pode ter se tornado, hoje, qualquer pessoa à sua volta - inclusive você.

\section{REFERÊNCIAS}

AMERICANAS.COM. Mini Drone Cheerson Cx10w Com Camera Hd Fpv Wifi. Disponível em: https://www.americanas.com.br/produto/22348498/mini-drone-cheerson-cx10w-com-camera-hd-fpv-wifi. Acesso em: 4 de set. 2018.

ANAC. Orientações para usuários de drones. Disponível em: http:// www.anac.gov.br/assuntos/paginas-tematicas/drones/orientacoes_para_usuarios.pdf. Acesso em: 7 de set. 2018.

ANAC. Regulamento Brasileiro da Aviação Civil Especial (RBAC-E $\mathbf{n}^{\circ}$ 94). Aprovado pela Resolução ${ }^{\circ} 419$, de 2 de maio de 2017.

ANATEL. Drones devem ser homologados para evitar interferências. Disponível em: http://www.anatel.gov.br/institucional/ultimas-noticiass/2-uncategorised/1485-drones-devem-ser-homologados-para-evitar-interferencias. Acesso em: 6 de set. 2018.

ARISTÓTELES. Política. Traduzido por Roberto Leal Ferreira. São Paulo: Martins Fontes, 2002.

BGR. This robotic bee uses static eletricity to stick to surfaces. Disponível em: https://bgr.com/2016/05/20/harvard-mit-robobee-perching/. Acesso em: 5 de out. 2018.

74 ORWELL, George. 1984. Tradução de Alexandre Hubner e Heloisa Jahn. São Paulo: Companhia das Letras, 2009. 
BR.GEARBEST.COM. Hover Camera Passport RC Drone Dobrável de Bolso - PRETO. Disponível em: https://br.gearbest.com/rc-quadcopters/pp_1058692.html. Acesso em: 4 de set. 2018.

BRANDEIS, Louis D; WARREN, Samuel D. The right to privacy. Harvard Law Review, v. 4, n. 5, dec. 15, 1890.

BRASIL. Constituição (1988). Constituição da República Federativa do Brasil. Brasília, DF: Senado Federal: Centro Gráfico, 1988. 292 p.

BRASIL. Código Civil Brasileiro. Lei no 10.406, de 10 de janeiro de 2002. Legislação Federal. Disponível em: http://www.planalto.gov.br/ ccivil_03/Leis/2002/l10406.html. Acesso em: 12 jun. 2018.

CAMERANO, Ana Cláudia Santos. Novas ameaças e o advento dos drones: a ótica brasileira. Artigo científico. Universidade Federal de Santa Catarina: 2015. Disponível em: https://www.defesa.gov.br/ arquivos/ensino_e_pesquisa/defesa_academia/cadn/artigos/xii_cadn/ novas_ameacas.pdf. Acesso em: 24 jul. 2018.

CAMPOS PEIXOTO, Erick Lucena; EHRHARDT JÚNIOR, Marcos. Breves notas sobre a ressignificação da privacidade. Revista Brasileira de Direito Civil. Belo Horizonte, v. 16, p. 35-56, abr./jun. 2018.

CANTALI, Fernanda Borghetti. Direitos da personalidade: disponibilidade relativa, autonomia privada e dignidade humana. Porto Alegre: Livraria do Advogado Editora, 2009.

CASTELLS I MARQUÈS, Marina. Drones civiles. In: Navas Navarro, Susana. Inteligencia artificial, Tecnologia, Derecho. Capítulo II. Valencia: Tirant lo Blanc, 2017.

CASTRO, Fábio. ESTADÃO. Cientistas desenvolvem 'drone-inseto' para fazer polinização. Disponível em: https://ciencia.estadao.com. $\mathrm{br} /$ noticias/geral,cientistas-desenvolvem-drone-inseto-para-fazer-polinizacao,70001658819. Acesso em: 13 de out. 2018.

CLARKE, Roger. The Regulation of Civilian Drones Impacts on Behavioural Privacy. Computer Law \& Security Review: 2014. p. 36.

COOLEY, Thomas McIntyre. A treatise on the law of torts, or the wrongs which arise independent of contract. Chicago: Callaghan and Company, 1879. Disponível em: http://www.hathitrust.org. Acesso em 21 de mai. 2018.

COPLE, Julia. Cauã Reymond decide processar fotógrafo que fez imagens do ator nu dentro de casa. Jornal Extra. Disponível em: https:// 
extra.globo.com/casos-de-policia/caua-reymond-decide-processar-fotografo-que-fez-imagens-do-ator-nu-dentro-de-casa-22296510.html. Acesso em: 13 jun. 2018.

CORREIA, Pedro Miguel Alves Ribeiro. JESUS, Inês Oliveira Andrade de. 0 lugar do conceito de privacidade numa sociedade cada vez mais orwelliana. Rev. Direito, Estado e Sociedade, n. 43, p. 135 a 161. Lisboa: 2013.

DECEA. Conheça as orientações. Disponível em: https://www.decea. gov.br/drone/. Acesso em: 7 de set. 2018.

FEDERAL AVIATION ADMINISTRATION. Summary of small unmaned aircraft rule (part 107). USA: 2016.

G1. Com preço menor, 3 milhões de drones devem ser vendidos em 2017, diz consultoria. Disponível em: http://g1.globo.com/tecnologia/ noticia/com-preco-menor-3-milhoes-de-drones-devem-ser-vendidos-em-2017-diz-consultoria.ghtml. Acesso em: 19 abr. 2018.

G1. Drone flagra mulher de topless pegando sol em telhado de edifício. Disponível em: http://g1.globo.com/planeta-bizarro/noticia/2014/10/drone-flagra-mulher-de-topless-pegando-sol-em-telhado-de-edificio.html. Acesso em: 17 de abr. 2018.

GHOSH, Bobby; THOMPSON, Mark. The CIA's Silent War in Pakistan. Time. Washington: 2009. Disponível em: http://content.time.com/time/ magazine/article/0,9171,1900248,00 html. Acesso em: 11 ago. 2018.

GOULART, Guilherme. Condicionamento, liberdade e privacidade: compreendendo as novas tecnologias por meio do 'Admirável Mundo Novo'. Revista Diálogos do Direito, v. 4, n. 6, Jul/2014.

GRANEMANN, Emerson. Os desafios da regulamentação do uso de drones no Brasil. 2018. Disponível em: https://droneshowla.com/ artigo-os-desafios-da-regulamentacao-do-uso-de-drones-no-brasil/. Acesso em: 20 de out. 2018.

GROSS, Hyman. Privacy - Its Legal Protection. New York: Oceana, 1964. HARARI, Yuval Noah. Homo Deus: uma breve história do amanhã. Tradução: Paulo Geiger. 1a ed. São Paulo: Companhia das Letras, 2016. p. 12.

HORGAN, John. Why drones should make you afraid very afraid. Scientific American, fev. 2013. Disponível em: http://blogs.scientifica- 
merican.com/cross-check/why-drones-should-make-you-afraid-very-afraid/. Acesso em 17 set. 2018.

JORNAL EXTRA ONLINE. Drone sobrevoa mansão e flagra Gisele Bundchen em momento íntimo com o marido. Disponível em: https://extra.globo.com/famosos/drone-sobrevoa-mansao-flagra-gisele-bundchen-em-momento-intimo-com-marido-21698916.html. Acesso em: 13 de abr. 2018.

LOCKE, John. Segundo tratado sobre o governo civil: ensaio sobre a origem, os limites e os fins verdadeiros do governo. Petrópolis: Vozes, 1999.

MARMELSTEIN, George. Curso de direitos fundamentais - 5. Ed. São Paulo: Atlas, 2014.

MATTOS, Nelson. A popularização dos drones. Disponível em: https:// gauchazh.clicrbs.com.br/opiniao/noticia/2015/11/nelson-mattos-a-popularizacao-dos-drones-4917336.html. Acesso em: 12 ago. 2018.

MILL, John Stuart. A liberdade. 1 ed. São Paulo: Martins Fontes, 2000.

MILLER, Arthur. The Assault on Privacy. Ann Arbor: University of Michigan Press, 1971.

MORAES, Alexandre de. Direito Constitucional. 24. edição. São Paulo: Atlas, 2009.

MOREIRA, Gabriela. ESPN. Exclusivo: Grêmio usou drone para espionar rivais durante o ano; veja flagra em treino do Lanús. Disponível em: http://www.espn.com.br/noticia/744582_exclusivo-gremio-usou-drone-para-espionar-rivais-durante-o-ano-veja-flagra-em-treino-do-lanus. Acesso em: 11 de mar. 2018.

ORWELL, George. 1984. Tradução de Alexandre Hubner e Heloisa Jahn. São Paulo: Companhia das Letras, 2009.

PARLAMENTO EUROPEU. Comissão dos Assuntos Jurídicos. Proposta de resolução que contém recomendações à Comissão Jurídica sobre disposições de Direito Civil e Robótica. 2017. Disponível em: http://www.europarl.europa.eu/sides/getDoc.do?pubRef=-//EP// TEXT+REPORT+A8-2017-0005+0+DOC+XML+V0//PT. Acesso em: 17 de out. de 2018.

PARLAMENTO EUROPEU. Direcção-Geral de Políticas Internas. Estudo das implicações da utilização civil de drones para a privacidade e para a proteção de dados. 2016. Disponível em: http://www. 
europarl.europa.eu/RegData/etudes/IDAN/2015/519221/IPOL_ IDA(2015)519221_PT.pdf. Acesso em: 18 de out. 2018.

PARLAMENTO EUROPEU. Drones: PE aprova primeiras regras a nível europeu para garantir segurança. 2018. Disponível em: http://www. europarl.europa.eu/news/pt/press-room/20180607IPR05239/drones-pe-aprova-primeiras-regras-a-nivel-europeu-para-garantir-seguranca. Acesso em: 23 de out. 2018.

PARLEMENT FRANÇAIS. Arrêté du 17 décembre 2015 relatif à l'utilisation de l'espace aérien par les aéronefs qui circulent sans personne à bord. France: 2015.

REALE, Miguel. Lições preliminares de direito. 27 ed. São Paulo: Saraiva, 2002. p. 14.

RECORD TV. Homem usa drone para espionar vizinha. Disponível em: http://recordtv.r7.com/balanco-geral/videos/homem-usa-drone-para-espionar-vizinha-21102018. Acesso em: 17 de abr. 2018.

SCHWAB, Klaus. A quarta revolução industrial. Tradução: Daniel Moreira Miranda. 1aㅡ ed. São Paulo: Edipro, 2016.

SCHWAB, Klaus. The Fourth Industrial Revolution: What It Means and How to Respond. Foreign Affairs, Dez. 2015. Disponível em: https://www.foreignaffairs.com/articles/2015-12-12/fourth-industrial-revolution. Acesso em: 23 jul. 2018.

SENADO NOTÍCIAS. Senado aprova uso de drones por forças policiais. Disponível em: https://www12.senado.leg.br/noticias/audios/2017/12/ senado-aprova-uso-de-drones-por-forcas-policiais. Acesso em: 19 de mai. 2018.

TESLA, Nikola. Method of and apparatus for controlling mechanism of moving vessels or vehicles. Pat. 68.809. New York: 1898. Disponível em: https://patents.google.com/patent/US613809A/en. Acesso em: 07 ago. 2018.

VIANNA, Túlio Lima. Transparência Pública, Opacidade Privada: o direito como instrumento de limitação do poder na sociedade. Revan: Rio de Janeiro, 2007. p. 197.

VILLAR GOMEZ, Andre. Pesadelo high-tech: a quarta revolução industrial e o fim do mundo que conhecemos. Revista Libertas, v. 17. Juiz de Fora: 2017. 